\title{
Rating of Investments Funds Using the Capital Asset Pricing Model: Experience of Ukraine
}

\author{
Zoriana Matsuk* \\ Department of Finance \\ Ivano-Frankivsk National Technical \\ University of Oil and Gas \\ Ivano-Frankivsk, Ukraine \\ https://orcid.org/0000-0002-4303-9875
}

\author{
Lidiia Tryshak \\ Department of Finance \\ Ivano-Frankivsk National Technical \\ University of Oil and Gas \\ Ivano-Frankivsk, Ukraine \\ https://orcid.org/0000-0002-3605-8672 \\ Iryna Danyliuk-Chernykh \\ Department of Finance \\ Ivano-Frankivsk National Technical \\ University of Oil and Gas \\ Ivano-Frankivsk, Ukraine \\ https://orcid.org/0000-0002-6413-3991
}

\author{
Vira Shyiko \\ Department of Finance \\ Ivano-Frankivsk National Technical \\ University of Oil and Gas \\ Ivano-Frankivsk, Ukraine \\ https://orcid.org/0000-0002-2822-0641
}

\begin{abstract}
The rating of the unit investment funds of the open and interval types, which invest more then 30 percent of their assets to the shares in Ukraine, was done using CAPM. The sample of data from the investment funds that work on the securities market in Ukraine more than 5 years was compiled. The indicators of funds' over yield, as the difference between fund's yield and the minimum allowable rate of return on investment in Ukraine were calculated. Using the least square method the linear regression equation in the form of a CAPM $r_{f}-\left(r_{f}(U S A)+r_{\text {country }}\right)=\alpha_{f}+\beta_{f} *\left(r_{m}-\left(r_{f}(U S A)+r_{\text {country }}\right)\right)+\varepsilon$ was built. For further research the investment funds, that have the coefficient of $\beta_{f} \geq 0,3$ and the coefficient of determination $R^{2} \geq 0,5$, where selected. The statistical significance of the regression equations obtained using the $F$ criteria was checked. The hypothesis about the equality of coefficients ${ }^{\alpha_{f}}$ and ${ }^{\beta_{f}}$ were researched. The tables of the tstatistics for the each of hypothesis were built. The investment funds by the value of the coefficient ${ }^{\beta_{f}}$ were grouped. As a result of rating, the investor will have the opportunity to select the group of funds that is acceptable to him in terms of profitability and risk.
\end{abstract}

\section{Keywords - CAPM; Investment fund; Rating}

\section{INTRODUCTION}

The process of rating provides the set of actions during the cooperation between the rating agency and the customer company. It assures the integrity and authenticity of rating's researches. In order to be useful for customer, rating must be objective and substantiated, available and periodically updated. In the foreign practice two approaches to the credit scores of the customer company are used. These are rating based on the analysis and based on the modelling. In the first case analysts get financial information directly from the customer. Using the mathematical methods, they do different calculations and conclude about the financial state and the risks of the company. The second case allows for the analysis of the financial data using the mathematical models.

During the financial assets trading investor can give himself an estimate of the investment funds activities in the short-term perspective studying its portfolio of the financial assets. Usually the information about the state of the portfolio appears in the free access with a delay and renews frequently once a month. But the investment manager makes investment decisions every day. For example, in the USA there is a practice, when at the end of the reporting period the managers of the investment funds for getting additional premiums for the effectiveness of fund management, sell from the portfolio shares, which value decrease during the reporting period, and buy those, which value increase. These actions increase the fund's expenses and form in investors false impression about the timeliness of effective investment decisions by investment managers. So, during the formation of the investment funds rating the important methodological problem appeared. The rating of companies, banks and countries includes the analysis of the system of indicators, which characterize the financial stability of these institutes. While the main characteristics of the investment funds are the level of profitability and risk, which are changed multivector.

Nowadays the investment funds' rating is done by the "Expert-Rating" among the authorized rating agencies. On the website of this agency we can find information about the rating for two asset management companies: "Kinto" and "National Reserve" (Expert Rating, 2019). These ratings were assigned in 2009 and in 2010. In the Memorandum of cooperation, which was established between UAIB and Expert-Rating, agency doesn't support the obligatory rating system and opposes against the mandatory rating of AMC and investment funds.

Sufficiently full and useful for further analysis is webpage www.investfunds.com.ua, which has the database of the assets management companies with the characteristics of the investment funds, their investment directions and the total net asset value. The rating of the investment funds is formed by such indicators: yield, net asset value and the amount of involved resources. But they don't give the general rating of the investment funds. Except this on the webpage there is information that they the position of the fund or asset management company in the rating does not 
guarantee high level of profitability and reliability in the future (Investfunds, 2019). Moreover, in practice there is a thought, that the rating of investment fund is not important because each of investors can independently determine the ratio between shares and bonds in his investment portfolio and buy investment certificate of the relevant funds.

Since 2011 on the website of Ukrainian association of investment business (UAIB) there is information about the coefficient of Sharpe for investment funds (UAIB, 2019). In our opinion this coefficient is not the indicator that can give for the investor an opportunity to take the efficient investment solution. By the way, Sharpe W. in his research studied the activities of the biggest 100 stock funds for the period from 1985 to 1994 and concluded that provided the scale effect the big funds always had the smaller loss and demonstrated the higher profitability than the smaller funds. Except this, the yield of the funds is calculated without the commission for the sale of investment certificates and taxes, which can minimize the benefits of the strategy, which provides for regular withdrawal of money from one fund for investment in top-10 (Sharpe, 1995). In general, the coefficient of Sharpe shows how many units the investor will get for risk he took, and cannot be the universal indicators for investors with different risk appetites.

In 2014 the researchers of Stanford University Jonathan Berk and Jules $H$. van Binsbergen, the University of Pennsylvania (2015) published the Paper, in which they used the Capital Asset Pricing Model (Lintner, 1965; Sharpe, 1964; Black, 1972) for the estimation of the results of stock funds activity. For many years this model was supported and criticized by a large number of scientists. Er. H. and Hushmat A. (2017) using the CAPM established the technical rules of the futures trading. Zaremba (2014) confirmed that the CAPM didn't characterize the connection between risks on the foreign level unlike the national level. Fama E. F. Ta MacBeth J. D. (1973) demonstrated that on the first step it was possible to calculate beta coefficient in time regression, and on the second level - the regression of the intersection of all available individual income from shares by the beta coefficient. In the latest years a lot of mathematics and computer scientists paid their attention to the development of optimal algorithms for financial assets trading. But most of these algorithms cannot optimally predict market behaviour with significant accuracy.

None of the proposed by scientists' methods of investment funds rating can take into accounts the full extent of the investment risk and is not universal for the all of types of the funds. So, we think it is expedient to calculate the indicators of the unit investment funds activities using the CAPM for their further rating.

The paper is organized as follows. After the introduction we present the output data, which is used as a starting point for the rating. Section 3 outlines methodology. Results are discussed in Section 4 and final Section 5 concludes the paper and suggests the direction of future research.

\section{BACKGROUND}

The output data contains the indicators of the nominal month yield of the share investment funds during 2015-2018. We took into consideration only open and interval funds with the public emission of the investment certificates. These data are public and $30 \%$ of assets in their portfolios are in stocks. According to the information of UAIB at the end of 2018 the general amount of them was 41. For rating we chose 23 investment funds (UAIB, 2019).

While more than $90 \%$ of operations with shares were done on the Ukrainian stock exchange, for further calculation we used the data from Ukrainian stock exchange (UX, 2019). The index of UX during the period 2016-2018 grew up from 662,13 to 1363,02 . The nominal index is calculated in Hryvnia, because trading is held in national currency. Index of UX is calculated on the basis of 6 companies: Raiffeisen Bank Aval - 18,07\%; Centrenego - 25,85\%; Donbasenergo - 3,06\%; Motor Sich - 26,42\%; Turboatom - 8,62\%; Ukrnafta - 17,99\% (UX, 2019). Actually, the UX index doesn't show the real situation on the national stock market, but traditionally it is used as the indicator of securities market state in Ukraine. According to our calculation the average daily yield of the UX index was $0.16 \%$. The standard deviation was $1.341 \%$ in day and characterized the high level of volatility on the market during this period.

In the U.S.A and countries of Europe the indicator of the government bond yield as the risk-free interest rate is used. In average it veers from $8 \%$ till $10 \%$ and characterizes the high level of reliability of this financial instrument. Nowadays, as for Ukraine it is practically impossible to calculate the risk-free interest rate. The level of reliability of government bonds don't allow us to consider them as riskfree investment, due to significant volatility fluctuations (almost double for 10 years) on these instruments (Figure 1).

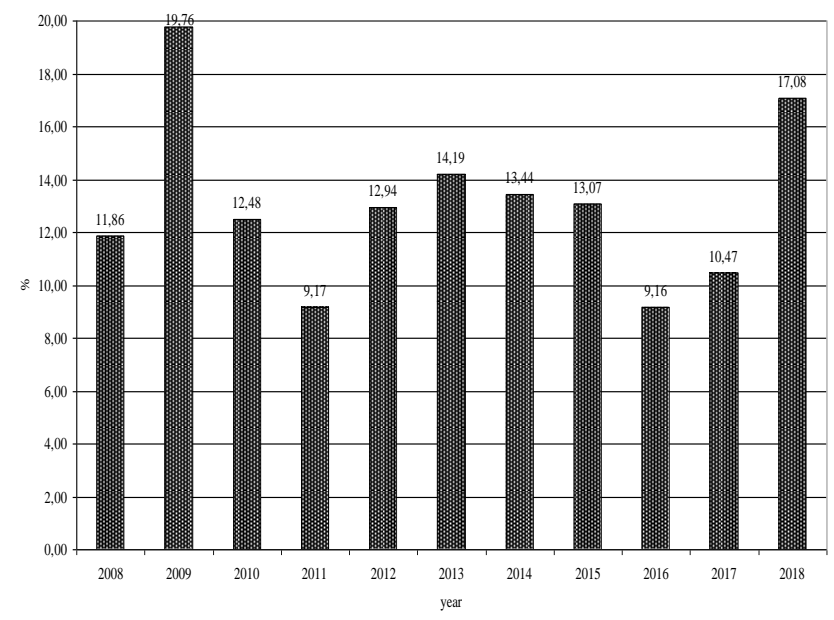

Fig. 1. Rate of return for the Ukrainian T-bills during 2008-2018

\section{Source: authors' calculations}

Because nowadays there is no alternative version of the risk-free investment in Ukraine, in the CAPM we used the methodology of foreign scientists (Stern, 2019) and one of the main investment rules is "the minimum allowable rate of return must be equal to the risk-free investment rate". For such countries as Ukraine that is characterized by the unstable national currency the minimum allowable rate of return will add in the yield of long-term US bonds and the premium for the risk of investing in the economy of a particular country. The last one is calculated on the basis of investment rating by the Moody's. Its value was ranged from $0.885 \%$ to $0.973 \%$ (Figure 2 ). 


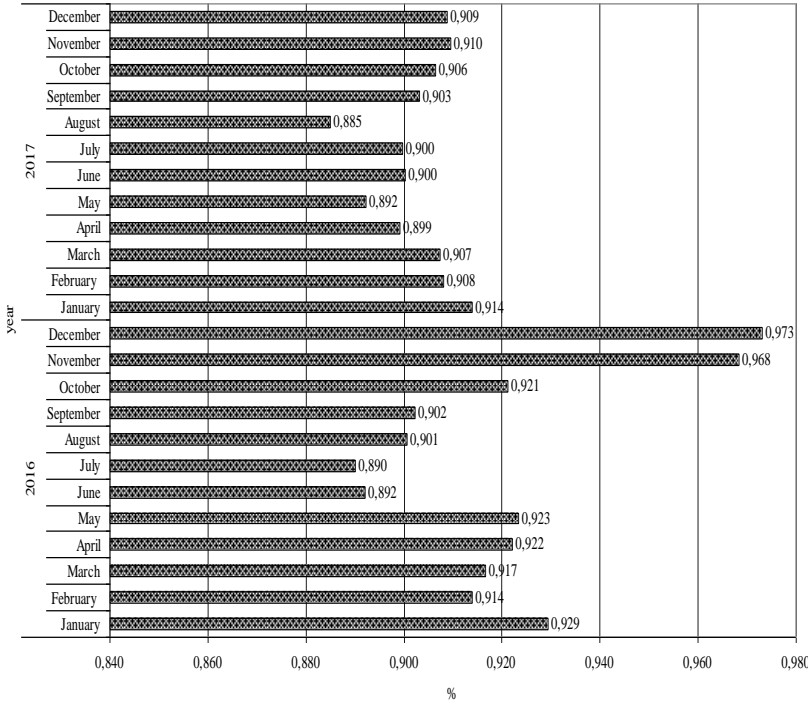

Fig. 2. The minimum allowable rate of return on investment for Ukraine during 2016-2017,\%

Source: authors' calculations

\section{Methodology}

Based on the data the indicators of upper yield for each found and in general for market portfolio were calculated as:

$$
\begin{aligned}
& \Delta r_{f}=r_{f}-r_{\min } \\
& \Delta r_{p}=r_{m}-r_{\min }
\end{aligned}
$$

where: $r_{f}$ - fund yield;

$r_{\min }-$ minimum allowable rate of return of investment;

$r_{m}$ - market yield.

The minimum allowable rate of return as the sum of the long-term US bonds yield and the risk premium for investing in a country's economy (after Moody's) was calculated this way (Rogulskiy, 2012):

$$
r_{\min }=r_{f(U S A)}+r_{\text {country }},
$$

where: $r_{f(U S A)}-10$-year US bond yield;

$r_{\text {country }}-$ a risk premium for investing in a country's economy.

For each fund the linear regression equation was built using the method of the least squares. It characterizes the dependence of the indicator of the upper yield of the fund on the indicator of upper yield of the market and is calculated as:

$$
r_{f}-\left(r_{f(U S A)}+r_{\text {country }}\right)=\alpha_{f}+\beta_{f} *\left(r_{m}-\left(r_{f(U S A)}+r_{\text {country }}\right)+\varepsilon,\right.
$$

where: $\beta_{f}$ - the coefficient of linear dependence on the upper yield of the fund $f$ on the upper yield of the market portfolio $\beta_{f}$;

$\alpha_{f}-$ free regression member; $\varepsilon$ - regression error.

Using the method of the least squares the estimation of the coefficient of regressions was obtained:

$$
\beta_{f}=\frac{\delta_{f m}}{\delta_{m}^{2}},
$$

where: $\delta_{f m}-$ co-variance of the upper yield of the fund $\mathrm{f}$ and the market portfolio; $\delta_{m}^{2}$ - variance of the market index yield.

$$
\alpha_{f}=\overline{y_{f}}-\beta_{f} * \overline{x_{f}},
$$

where: $\overline{x_{f}}-$ the average value of the upper yield of a market index; $\bar{y}_{f}$-average value of the upper yield of the fund.

The value of the obtained regression coefficients using the t-critical was calculated as:

$$
t_{\beta}=\frac{\beta}{\sigma_{\beta}}
$$

where: $\sigma_{\beta}-$ the standard error of the coefficient, which is less than the corresponding t-critical value of the Student distribution for the selected trust level with the number of degrees of freedom, which is equalled:

$$
n-(k+1) \text {, }
$$

where: $n$ - the number of observations;

$k$ - the number of variables.

\section{RESULTS AND DISCUSSION}

The calculations of regression coefficients according to the initial data are presented in the Table 1.

Further we consider the funds with the coefficient $\beta_{f} \geq 0.3$ and think that for the funds, which have $\beta_{f}<0.3$, the CAPM isn't adequate. Then we calculate the regression statistics for all funds and conclude that the coefficient of determination for the funds with $\beta_{f}<0.3$ is less than 0.5 and the regression equation characterize less than half the variance of the fund yield. The low level of the coefficient of determination shows the limp connection between the fund yield and the market yield and is explained by the specific of the fund's management or by the presence in its portfolio a lot of not circulating securities on the stock exchange. It confirms that these funds cannot be described by CAPM with the high probability.

After that we check the value of the received coefficient of regression by the t-criteria.

The hypothesis about the statistic value of the coefficient of the linear regression is rejected, if the calculated value is more then, table one 2.06. Thus, for the 6 investment funds we can build the regression equation of the fund's upper yield from market upper yield according to the CAPM. This equation will be statistically significant. 
TABLE I. RESULTS OF CALCULATIONS OF COEFFICIENTS OF REGRESSION

\begin{tabular}{|l|l|l|l|l|l|}
\hline No & $\begin{array}{l}\text { Investment } \\
\text { funds }\end{array}$ & $\begin{array}{l}\text { Upper } \\
\text { yield }\end{array}$ & $\begin{array}{l}\text { Standard } \\
\text { deviation }\end{array}$ & $\alpha_{f}$ & $\beta_{f}$ \\
\hline 1 & KINTO-Ekviti & 1.6910 & 2.9950 & 0.6849 & 0.0834 \\
\hline 2 & $\begin{array}{l}\text { KINTO- } \\
\text { Klasychnyy }\end{array}$ & 1.1902 & 1.9650 & 0.2783 & 0.0588 \\
\hline 3 & $\begin{array}{l}\text { KINTO- } \\
\text { Narodnyy }\end{array}$ & 0.1144 & 3.7524 & -0.7975 & -0.0267 \\
\hline 4 & $\begin{array}{l}\text { KINTO- } \\
\text { Kaznacheys'kyy }\end{array}$ & 1.7109 & 3.8700 & 0.7989 & 0.1388 \\
\hline 5 & $\begin{array}{l}\text { Tsentral'nyy } \\
\text { investytsiynyy } \\
\text { fond }\end{array}$ & -1.2481 & 3.6248 & -2.1600 & -0.0611 \\
\hline 6 & $\begin{array}{l}\text { Prominvest- } \\
\text { Keram }\end{array}$ & -0.7592 & 4.3826 & -1.6711 & -0.0810 \\
\hline 7 & Platynum & 1.8465 & 3.7396 & 1.5345 & 0.3183 \\
\hline 8 & Aurum & 3.3800 & 6.6938 & 2.4680 & 0.5280 \\
\hline 9 & Arhentum & 2.8703 & 3.3120 & 1.4583 & 0.3081 \\
\hline 10 & OTP Klasychnyy & 1.1041 & 0.2201 & 0.1922 & -0.0028 \\
\hline 11 & OTP Fond aktsiy & 3.6568 & 9.9228 & 5.7448 & 0.6691 \\
\hline 12 & Nadbannya & 2.6935 & 3.9075 & 1.7815 & 0.3888 \\
\hline 13 & Parytet & 1.2212 & 1.7030 & 0.3092 & 0.1307 \\
\hline 14 & $\begin{array}{l}\text { Al'tus } \\
\text { zbalansovanyy }\end{array}$ & 0.9475 & 0.7461 & 0.0355 & 0.0046 \\
\hline 15 & $\begin{array}{l}\text { Al'tus } \\
\text { stratehichnyy }\end{array}$ & 0.7906 & 0.8907 & -0.1214 & 0.0145 \\
\hline 16 & Al'tus depozyt & 1.0135 & 0.8595 & 0.1015 & 0.0074 \\
\hline 17 & Bonum-optimum & -0.2350 & 0.6875 & -1.1470 & 0.0352 \\
\hline 18 & TASK Resurs & 0.5645 & 3.5711 & -0.3475 & 0.1349 \\
\hline 19 & $\begin{array}{l}\text { UNIVER VV: } \\
\text { Zbalansovanyy }\end{array}$ & 1.5103 & 2.9780 & 0.5983 & 0.1686 \\
\hline 20 & VSI & 0.7315 & 6.7941 & -0.1805 & 0.5586 \\
\hline 21 & UNIVER MH & -0.1244 & 10.8169 & -1.0363 & 0.3697 \\
\hline 22 & UNIVER YAM & 2.5147 & 5.7298 & 1.6027 & 0.3550 \\
\hline 23 & DI “Platynum” & 0.8394 & 3.3169 & -0.0726 & 0.0782 \\
\hline & authors'calculations & & \\
\hline
\end{tabular}

Source: authors' calculations

TABLE II. STATISTICAL CHARACTERISTICS OF INVESTMENT FUNDS DURING 2016-2017

\begin{tabular}{|l|l|l|l|l|l|}
\hline No & $\begin{array}{l}\text { Investment } \\
\text { fund }\end{array}$ & $\begin{array}{l}\text { Coefficient of } \\
\text { determination }\end{array}$ & $\begin{array}{l}\text { t- } \\
\text { criteria } \\
\text { value }\end{array}$ & $\alpha_{f}$ & $\beta_{f}$ \\
\hline 1 & KINTO-Ekviti & 0.2010 & 0.9842 & 0.6849 & 0.0834 \\
\hline 2 & $\begin{array}{l}\text { KINTO- } \\
\text { Klasychnyy }\end{array}$ & 0.2161 & 1.0615 & 0.2783 & 0.0588 \\
\hline 3 & $\begin{array}{l}\text { KINTO- } \\
\text { Narodnyy }\end{array}$ & -0.0514 & 0.2469 & -0.7975 & -0.0267 \\
\hline 4 & $\begin{array}{l}\text { KINTO- } \\
\text { Kaznacheys'kyy }\end{array}$ & 0.2589 & 1.2852 & 0.7989 & 0.1388 \\
\hline 5 & $\begin{array}{l}\text { isentral'nyy } \\
\text { fond }\end{array}$ & -0.1216 & 0.5873 & -2.1600 & -0.0611 \\
\hline 6 & $\begin{array}{l}\text { Prominvest- } \\
\text { Keram }\end{array}$ & -0.1334 & 0.6455 & -1.6711 & -0.0810 \\
\hline 7 & Platynum & 0.5214 & 2.2284 & 1.5345 & 0.3183 \\
\hline 8 & Aurum & 0.5693 & 3.3211 & 2.4680 & 0.5280 \\
\hline 9 & Arhentum & 0.5316 & 2.2945 & 1.4583 & 0.3081 \\
\hline 10 & OTP Klasychnyy & -0.0927 & 0.4465 & 0.1922 & -0.0028 \\
\hline 11 & OTP Fond aktsiy & 0.5412 & 2.7408 & 5.7448 & 0.6691 \\
\hline 12 & Nadbannya & 0.5080 & 2.6099 & 1.7815 & 0.3888 \\
\hline 13 & Parytet & 0.5540 & 3.1913 & 0.3092 & 0.1307 \\
\hline 14 & $\begin{array}{l}\text { Al'tus } \\
\text { zbalansovanyy }\end{array}$ & 0.0443 & 0.2125 & 0.0355 & 0.0046 \\
\hline 15 & $\begin{array}{l}\text { Al'tus } \\
\text { stratehichnyy }\end{array}$ & 0.1177 & 0.5683 & -0.1214 & 0.0145 \\
\hline 16 & Al'tus depozyt & 0.0618 & 0.2971 & 0.1015 & 0.0074 \\
\hline 17 & Bonum-optimum & 0.3693 & 1.9059 & -1.1470 & 0.0352 \\
\hline 18 & TASK Resurs & 0.2727 & 1.3592 & -0.3475 & 0.1349 \\
\hline 19 & $\begin{array}{l}\text { UNIVER VV: } \\
\text { Zbalansovanyy }\end{array}$ & 0.4086 & 2.1470 & 0.5983 & 0.1686 \\
\hline 20 & VSI & 0.5871 & 2.9750 & -0.1805 & 0.5586 \\
\hline 21 & UNIVER MH & 0.5086 & 2.3212 & -1.0363 & 0.3697 \\
\hline 22 & UNIVER YAM & 0.5827 & 2.2868 & 1.6027 & 0.3550 \\
\hline 23 & DI "Platynum" & 0.2105 & 1.0325 & -0.0726 & 0.0782 \\
\hline Source: & authors'calculat & & & & \\
\hline
\end{tabular}

Source: authors' calculations
The list of the investment funds, that were selected for rating is shown in the Table 3 in the order of the increasing the coefficient $\beta_{f}$.

TABLE III. THE CHARACTERISTICS OF THE FUNDS, PARTICIPATE IN RATING DURING 2016-2017

\begin{tabular}{|l|l|l|l|}
\hline No & Investment funds & $\alpha_{f}$ & $\beta_{f}$ \\
\hline 1 & Arhentum & 1.4583 & 0.3081 \\
\hline 2 & Platynum & 1.5345 & 0.3183 \\
\hline 3 & UNIVER YAM & 1.6027 & 0.3550 \\
\hline 4 & Nadbannya & 1.7815 & 0.3888 \\
\hline 5 & Aurum & 2.4680 & 0.5280 \\
\hline 6 & OTP Fond aktsiy & 3.7448 & 0.6691 \\
\hline
\end{tabular}

Source: authors' calculations

The final rating of the investment funds is in the Table 4.

Taking into account the insignificant amount of the investment funds for the conducted analysis and the low level of national securities market liquidity, the CAPM cannot exactly appreciate the funds' activities. Greater accuracy may be reached using the bigger data (amount of the investment funds) and the bigger period of valuation. Regardless of the result, we think that this research can give positive theoretical and practical effect.

TABLE IV. THE RATING OF THE SHARE INVESTMENT FUNDS BASED ON THE END OF 2017

\begin{tabular}{|l|c|l|c|}
\hline Investment fund & $\beta_{f}$ & $\alpha_{f}$ & Rang \\
\hline \multicolumn{4}{|c|}{ Group I } \\
\hline OTP Fond aktsiy & 0.6691 & 3.7448 & I \\
\hline Aurum & 0.5280 & 2.4680 & II \\
\hline \multicolumn{3}{|c|}{ Group II } \\
\hline Nadbannya & 0.3888 & 1.7815 & III \\
\hline UNIVER YAM & 0.3550 & 1.6027 & IV \\
\hline Platynum & 0.3183 & 1.5345 & V \\
\hline Arhentum & 0.3081 & 1.4583 & VI \\
\hline
\end{tabular}

Source: authors' calculations

We could select two groups of the funds with the approximate investment style and estimate the efficiency of their investment managers' activity. Graphically the investment funds in the coordinates of beta-yield are depicted in Figure.3

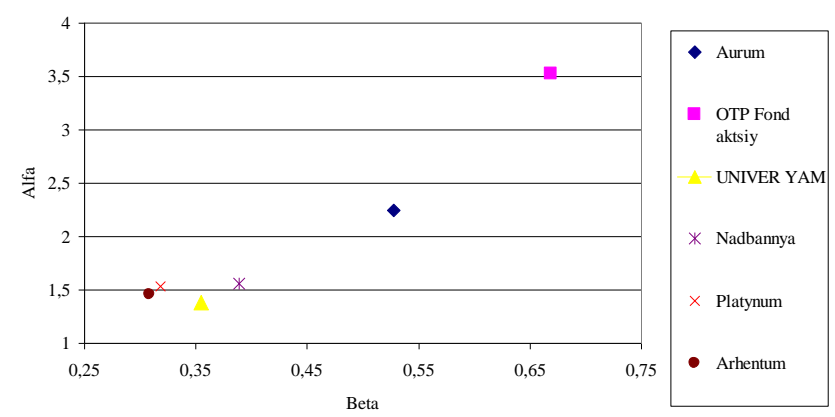

Fig. 3. The investment funds in the coordinates of beta-yield at the end of 2017

Source: authors' calculations

Using the lines, we selected the frameworks of the intervals of the coefficient. They are the frameworks of the investment funds groups in the rating. Theoretically we selected 4 groups of the funds: 


$$
\begin{gathered}
1 \leq \beta_{f}<0.75 ; \\
0.75 \leq \beta_{f}<0.50 ; \\
0.50 \leq \beta_{f}<0.25 ; \\
0.25 \leq \beta_{f} \leq 0 .
\end{gathered}
$$

Each group includes funds, which meet the specified criteria. The distance between the points which characterize the fund and the SML is the coefficient ${ }^{\alpha_{f}}$. It is calculated as the product ${ }^{\beta_{f}}$ on the upper yield of the index portfolio.

\section{CONCLUSION}

In this Paper author evaluated the investment funds explaining profitability of funds based on risk level. Author believes that using the coefficients $\alpha_{f}$ and $\beta_{f}$ in rating of the investment funds makes better the statistic and economic value for studying their level of yield. The higher coefficient $\beta_{f}$ leads to the higher systemic risk and the higher required return on the financial assets. This research also can help practices of the rating agencies in the process of the development of the expert automated systems for analysis and explaining the profitability of the investment funds.

\section{REFERENCES}

[1] Expert Rating, 2019. [Online]. Available: http://www.expertrating.com/rating-list_reiting-list/. Accessed on: 20 February 2019

[2] Investfunds, 2019. [Online]. Available: http://investfunds.ua/assetmana /. Accessed on: 20 February 2019

[3] UAIB: Rating., 2019. [Online]. Available: http://www.uaib.com.ua/analituaib/rankings/ici/by_types/vidkr_ici/sh arp.html. Accessed on:20 February 2019
[4] W.F. Sharpe, "The Styles and Performance of Large Seasoned U. S. Mutual Funds", Published on the World Wide Web, pp. 1985 - 1994, March 1995.

[5] Berk Jonathan, Van Binsbergen, and H. Jules, "Assessing Asset Pricing Models Using Revealed Preference" (March 14, 2015). Available at SSRN: https://ssrn.com/abstract $=2340784$ or http://dx.doi.org/10.2139/ssrn.2340784

[6] J. Lintner, "Security prices, risk, and maximal gains from diversification", The Journal of Finance, vol. 20(4), pp. 587-615, 1965 DOI: $10.2307 / 2977249$.

[7] W. F. Sharpe, "Capital asset prices: A theory of market equilibrium under conditions of risk", The Journal of Finance, vol. 19(3), pp. 425442, 1964 DOI: 10.2307/2977928.

[8] F. Black, "Capital market equilibrium with restricted borrowing", The Journal of Business, vol. 45(3), pp. 444-455, 1972. http://dx.doi.org/10.1086/295472

[9] H. Er, \& A Hushmat,. "The application of technical trading rules developed from spot market prices on futures market prices using CAPM", Eurasian Business Review, vol. 7(3), pp. 313-353, 2017. https://doi.org/10.1007/s40821-016-0056-2

[10] E. F. Fama, \& J. D. MacBeth, "Risk, return, and equilibrium: Empirical tests", The journal of political economy, pp. 607-636, 1973. https://www.jstor.org/stable/1831028

[11] A. Zaremba, "Cross-Sectional Asset Pricing Models for the Polish Market", SSRN Electronic Journal, $2014 . \quad$ DOI: $10.2139 / \mathrm{ssrn} .2396884$

[12] UX. http://www.ux.ua/ru/index/stat/dailyhistory.aspx? code=UX (2019). Accessed 20 February 2019

[13] Stern. http://pages.stern.nyu.edu/ adamodar/ (2019). Accessed 20 February 2019

[14] V. Rogulskiy, "Features of using the CAMP model to calculate the discount rate", Efficient economy, No. 10. http://www.economy.nayka.com.ua/?op=1\&z=1458 Accessed 20 February 2019. 